\title{
A hazai regionális tudományról: eredmények és kihívások
}

\author{
Hungarian regional science: achievements and challenges \\ LENGYEL IMRE, NEMES NAGY JÓZSEF, \\ RECHNITZER JÁNOS, VARGA ATTILA
}

\begin{abstract}
LENGYEL Imre: egyetemi tanár, Szegedi Tudományegyetem, Gazdaságtudományi Kar, Közgazdaságtani és Gazdaságfejlesztési Intézet; 6722 Szeged, Kálvária sgt. 1.; ilengyel@eco.u-szeged.hu; https://orcid.org/0000-0002-9225-5320

NEMES NAGY József: professor emeritus, Eötvös Loránd Tudományegyetem, Regionális Tudományi Tanszék; 1117 Budapest, Pázmány Péter sétány 1/c.; nemesnagy@t-online.hu; https://orcid.org/0000-0001-8838-3752

RECHNITZER János: egyetemi tanár, Széchenyi István Egyetem, Kautz Gyula Gazdaságtudományi Kar, Regionális-tudományi és Közpolitikai Tanszék; 9026 Győr, Egyetem tér 1.; rechnj@sze.hu; https://orcid.org/0000-0001-7570-4238

VARGA Attila: egyetemi tanár, Pécsi Tudományegyetem, Közgazdaságtudományi Kar, Közgazdaságtan és Ökonometria Intézet; 7622 Pécs, Rákóczi út 80.; vargaa@ktk.pte.hu; https://orcid.org/0000-0001-7252-5648
\end{abstract}

KULCSSZAVAK: regionális tudomány; társadalmi térelmélet; regionális és városgazdaságtan; terület- és településfejlődés; terület- és vidékfejlesztési politika; tervezés és kormányzás; területi elemzési módszerek

Imre LENGYEL: professor, Faculty of Economics and Business Administration, University of Szeged; Kálvária sgt. 1., H-6722 Szeged, Hungary; ilengyel@eco.u-szeged.hu; https://orcid.org/00000002-9225-5320

József NEMES NAGY: professor emeritus, Department of Regional Science, Eötvös Loránd University; Pázmány Péter sétány 1/c., H-1117 Budapest, Hungary; nemesnagy@t-online.hu; https://orcid.org/ 0000-0001-8838-3752

János RECHNITZER: professor, Kautz Gyula Faculty of Business and Economics, Széchenyi István University; Egyetem tér 1., H-9026 Györ, Hungary; rechnj@sze.hu; https://orcid.org/0000-0001-7570-4238 Attila VARGA: professor, Faculty of Business and Economics, University of Pécs; Rákóczi út 80., H-7622, Pécs, Hungary; vargaa@ktk.pte.hu; https://orcid.org/0000-0001-7252-5648

KEYWORDS: regional science; theory of social space; regional and urban economics; regional and settlement development; regional and rural development policy; planning and governance; spatial analysis methods

\section{Bevezetés}

A Walter Isard kezdeményezése nyomán 1954-ben útjára indult regionális tudomány ("regional science") mára világszerte intézményesült, aktív intézményi keretekben fogja össze a társadalmi térbeliség, a területi folyamatok és a területi irányítás ügyeinek társadalomtudományi kutatását. E folyamatba a magyar ku-

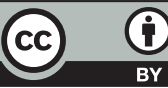


tatók és elsősorban a terület- és településfejlesztésben tevékenykedő, a tudományos kérdésekre is nyitott szakemberek már a múlt század hatvanas éveiben bekapcsolódtak. A hazai fejlődéstörténet legfontosabb momentumait már több tanulmány összefoglalta (Lengyel, Rechnitzer 2009). A tudományterület szempontjából kulcsfontosságúnak tartjuk, hogy a hazai regionális tudományt a közelmúltban (2017 októberében), hosszas előkészület után közzétett megújított akadémiai tudományos osztályozási rendszer (nomenklatúra) világosan elhelyezi a hazai diszciplináris térben. A többszintű osztályozási rendszerben Regionális tudományok elnevezéssel a Társadalomtudományok között találjuk a tudományterületet. Az osztályozás - a szakma tudományos testületeinek javaslatait figyelembe véve - öt kiemelt tématerületben fogja össze a kutatás fö irányait. Ezek: Társadalmi térelmélet, Regionális- és városgazdaságtan, a Terület- és településfejlődés gazdasági és társadalmi folyamatai, Terület- és vidékfejlesztési politika, tervezés és kormányzás valamint Területi statisztika és elemzési módszerek.

Ez a pozicionálás és belső tartalom megítélésünk szerint nyugvópontra helyezheti a regionális tudomány tartalmával kapcsolatos vitát. Visszatükrözi a tudományterület kezdetektől fogva egyértelműen látható, többágú diszciplináris gyökereit, az újabb generációk számára megjelöli a regionális tudomány alapvető tematikai „kínálatát”, ugyanakkor nem éles, de érzékelheto korlátot állít a „regionalistaság" határtalan kiterjesztésének. Egyben megtartja a nyitottságot, a kapcsolódási lehetőségeket, az együttmüködés útjait a más belső - nem kifejezetten területi - tudományos hangsúlyokkal jellemezhető, de a területi kérdéseket is érintő tudományterületeken dolgozó szakemberekkel, kutatókkal.

A regionális tudomány sikeres hazai pozicionálása igen örvendetes, megerősödött és megszilárdult tudományágunk hazai bázisa: az elmúlt tíz évben a Regionális Tudományok Bizottsága (RTB) köztestületi tagjainak száma 60-ról 150-re nőtt, a Magyar Regionális Tudományi Társaság (MRTT) aktív (fizető) tagsága is 200 fölötti, és eddig 130 fó szerzett regionális tudományi doktori címet. De ezek a sikerek nem fedhetik el azt a tényt, hogy tudományterületünk sok szempontból kritikus időszakot él át. Véleményünk szerint a hazai regionális tudomány hat komoly kihívással néz szembe:

1. A regionális tudomány hazai mühelyei széttöredezettek, a kutatások koordináltsága nem elégséges sem a Közgazdaság-és Regionális Tudományi Kutatóközpont Regionális Kutatások Intézetén (KRTK RKI) belül, sem az egyetemi és a kutatóintézeti múhelyek, valamint a gazdasági tanácsadó szervezetek között.

2. A regionális tudomány pályázati aktivitása és a tudomány képviselete a pályázati döntéshozatalban alacsony szintü.

3. Komoly gondok vannak a tudományos utánpótlás terén: mesterprogramok már csak kevés helyen működnek, ugyanakkor a regionális tudományi PhD-fokozattal rendelkezők csak korlátozottan vesznek részt a szakmai szervezetek (RTB, MRTT) munkájában. 
4. A generációváltás kihívásai: az MTA doktora fokozattal rendelkező kutatók száma fokozatosan csökken a tudományos mühelyekben. A korábbi egy-egy meghatározó vezető helyett „policentrikusabb” lett a vezető kutatók összetétele.

5. Ugyan a helyzet folyamatosan javul ezen a téren, a hazai regionális tudomány a szükségesnél még mindig alacsonyabb szinten reprezentált a nemzetközi kutatások élvonalában (csak néhány műhely publikál a magas kategóriás lapokban).

6. A társadalmi szerepvállalás szintje a kívánatosnál gyengébb: a regionális tudomány jelenléte mind a szakpolitikai tanácsadásban, mind a szélesebb nyilvánosságban alacsony szintü.

Tanulmányunk e kihívásokat részletezi, javaslatokat kínálva kezelésükre. A közelmúlt, napjaink és a jövő időkeretére összpontosítva igyekszünk helyzetelemzést adni, közös gondolkodásra, vitára, megoldáskeresésre bíztatva az egész szakmát. A kutatási kérdéskörön túlmenően kitekintünk a diszciplína oktatási, szakképzési jellemzőire.

\section{Helyünk a hazai és nemzetközi tudományos kapcsolatrendszerben}

A pontos számbavétel korlátai, a többes és esetenként időben is változó tudományos identitás és aktivitás okán a regionális tudományhoz kötődő, aktív hazai szakemberek számát ma 200 fő körülire tehetjük, az RTB köztestületi és az MRTT tagjait idesorolva. Közöttük kétharmadnyi a férfi, egyharmadnyi a nő. A regionalista kör három, nagyjából azonos létszámú generációs csoportba tartozik: az 1990 előtt pályájukat kezdők, az 1990-2000 között indulók és a 21. században pályát kezdő generáció. $\mathrm{E}$ három csoport tagjai eltérő tevékenységi súlypontokkal, pozíciókkal, egy-egy intézményhez kötődve vannak jelen az ország minden régiójában. Alapképzettségüket tekintve a ma regionális kutatással foglalkozók két legnagyobb csoportjának tagjai közgazdászként és geográfusként indultak, de sok, más alapképzettségü kollégánk útja is elvezetett a regionalisták közé.

\section{Mühelyek}

A hazai regionális tudomány ma is meghatározó intézménye a KRTK RKI, amely jelenleg öt osztállyal működik, vezető munkatársai közt iskolateremtő kollégákat találunk. Az intézet egységes kutatási arculata nem jelölhető ki, kutatói a regionális tudomány számos témakörében folytatnak alap- és alkalmazott kutatásokat. Egy-egy vezető kutató körül kisebb-nagyobb műhelyek alakultak ki, de a belső kapcsolatok esetlegesek a szervezeti egységek és kutatói közösség között. Az MTA kutatóközpontok felállításával (2014) a korábban önálló egység alárendelt intézetté vált, ami évekre visszavetette a kutatásokat, az új központban még nem szerveződtek belső, intézetek közötti kutatási együttműködések. Generációváltás 
jellemzi a RKI-t, a vezető kutatók száma folyamatosan csökken (jelenleg egy aktív MTA tagja és négy MTA doktora), a kutatói karrier építése kevésbé tervszerü, döntően egyéni törekvések függvénye a siker, a külső motivációk szerepe csökken (például az MTA doktora cím jelentősége drasztikusan csökken az egyetemi tanári kinevezéseknél). Ugyanez jellemző a nemzetközi kapcsolatokra is.

Az elmúlt harminc évben karakteres egyetemi kutatóbázisok jöttek létre: a Szegedi Tudományegyetem (SZTE), a Pécsi Tudományegyetem (PTE), az Eötvös Loránd Tudományegyetem (ELTE), a Miskolci Egyetem (ME), a Széchenyi István Egyetem (SZE), a Szent István Egyetem (SZIE), a Nyugat-magyarországi Egyetem (NYME) és a Soproni Egyetem (SOE) bázisain. Ezek részben tanszéki, intézeti keretekben és doktori iskolákban müködnek. Az egyetemi bázisok megerősödésének eredménye, hogy új kutatási irányok jelentek meg, a regionális tudományhoz kapcsolható minősítések száma növekedett, hogy határozott fiatalítás tapasztalható az intézményekben, s hogy a szakterület oktatói egyre több felsőoktatási egységben megtalálhatók. A generációváltás az egyetemi egységek vezető posztjain is zajlik. Az egyetemi oktatói gárdával szemben támasztott többes követelményrendszer (oktatás, kutatás, szakmai társadalmi aktivitás) kihívásai gyakran ellentétesek egymással.

Ugyan a folyamat már korábban megkezdődött, de az elmúlt években egyre határozottabban jelentek meg területi elemzésekkel foglalkozó gazdasági társaságok, ezek közül néhány tanácsadás mellett kutatásokat is végez. A piaci szereplők többsége beágyazódott bizonyos területi intézményekbe vagy azok különféle szerveibe, így biztosítják működésük tartós feltételeit. Másokat az aktuális kormányzatok tüntettek ki megbízásokkal a területi politika elemzésére, annak egyes vagy általános jegyeinek tanulmányozására. A gazdasági alapon működő szervezetek jobb esetben igyekeztek megnyerni a regionális tudomány vezeto", mértékadó szereplőit elemzéseikhez. Sajnálatos, hogy az elkészült elemzések alig kerülnek a szakmai nyilvánosság elé, azokat elvétve adják közre, így a valós szakmai kontrollok érvényesüléséről nem tudunk beszámolni.

Új jelenségként kell említenünk, hogy nagy pénzügyi erőforrással rendelkező közintézmények (pl. Magyar Nemzeti Bank) kutatóhelyeket támogatnak a regionális tudományhoz is kapcsolható gazdaságpolitikai célok elemzésére, vagy éppen a hagyományos tudományos képzési rendszer megújítása érdekében szponzorálnak egyetemi egységeket (pl. doktori képzés). A kutatási egységként is értelmezhető támogatott szervezetek müködési hatását a regionális tudomány szempontjából még nem lehet reálisan értékelni. Kedvezőbb kutatási körülményekkel rendelkeznek - vélhetően időszakosan -, mint a hagyományos kutatóhelyek, de irányukban a szakmai fenntartások fennmaradnak, különösen azért, mert működésük (a támogatás megszerzésének módja és felhasználási szerkezete, az eredmények közreadása stb.) nem mindig nyilvános, vagy tevékenységük gyakran nem követhető nyomon. 


\section{A tudományos eredmények közreadása}

A regionális tudomány korábban két könyvsorozatot működtetett, a Studium Regionum (1987-2010 között Dialóg Campus, 2016-tól újraindult, 2019-től Ludovika Kiadó), a Modern Regionális Tudomány (Akadémiai Kiadó, 2009-2016 között 11 kötettel). A Studium Regionum 2016-ban újraindult sorozatában eddig három monográfia és egy tanulmánykötet jelent meg. A könyvek mindkét sorozatban lektorálásra kerültek, a szerzőket a szerkesztőség kérte fel, vagy önmaguk nyújtottak be szinopszist, amit a szerkesztőség értékelt és jelezte a megjelenés támogatását. A kiadás költségeit, esetenként eltérő mértékben, a szerző biztosítja. Szakmai érdeklődés mutatkozik az új Studium Regionum sorozat iránt, a potenciális szerzőktől inkább ajánlatok érkeztek, még nem látszik, hány munka készül az ígéretekből, a kiadó jelenleg három mű szerkesztésén dolgozik.

Sikeres (kis) monográfia- vagy tanulmánysorozatok az elmúlt években több egyetemen is megjelentek (ELTE, SZTE, doktori iskolai évkönyvek, PTE, SZE), amelyek egy-egy műhelyt, annak munkatársait, alkotó közösségek munkáját, konkrét kutatások eredményeit mutatták be. A helyi, egyetemi kiadóknál megjelenő könyvek döntően helyi publikációknak tekinthetők, gyakran nem is kerülnek könyvárusi forgalomba, így szakmai hozzáférésük nem teljes körü. Esetenként találkoztunk elektronikus, online változatokkal is.

Egyedi kiadványok (doktori disszertációk, tanulmány-, konferencia-, emlékés tisztelgő kötetek, kutatási beszámolók) nagy számban jelentek meg a regionális tudományhoz kapcsolódóan. A publikációk egy-egy iskola, személyiség vagy kutatási program, esetenként tematikus konferenciák eredményeit adják közre, a terjesztésük intézményesen és/vagy szakmai hálózatokon keresztül történik (gyakran elektronikus formában is elérhetők), és a közölt kutatási eredmények csak áttételesen - véletlenszerűen - épülnek be a regionális tudomány szakmai áramlásába.

Idehaza elsősorban két domináns és kellő múlttal rendelkező szakmai folyóiratban adhatók közre a regionális tudomány kutatási eredményei: a Tér és Társadalomban (MTA, évi négy szám, 1987-től, A kategória), valamint a Területi Statisztikában (KSH, évi hat szám, indulás 1968, 1988-1996 között szünetelt, 1996-tól ismét megjelenés, A kategória). Hazai angol nyelvü folyóirat a Regional Statistics (KSH, évi két szám, 2011-től, B kategória). Az utóbbi Scopus regisztrált, a Tér és Társadalom két kísérlet után csak 2023-ban nyújthatja be ismét a pályázatát erre a nemzetközi fórumra. E folyóiratok megtartása a diszciplína jövőjének egyik kulcskérdése. Az említett vezető folyóiratok közül a Területi Statisztika és a Regional Statistics a regionális tudomány kvantitatív elemzési irányzatának ad fórumot, az erősödő tekintélyű Tér és Társadalom legutóbbi időszakának jellemzője a tematikai sokszínűség, ami azonban a regionális tudomány egyes hagyományos témáinak háttérbe szorulásával járt. 
Dominánsan regionális témákra koncentrálva két egyetemi folyóirat jelenik meg kellő rendszerességgel: az Észak-magyarországi Stratégiai Füzetek (Miskolci Egyetem, 2004-tól, negyedéves folyóirat, C kategória) és a Tér-Gazdaság-Ember (Széchenyi István Egyetem, 2013-tól, negyedéves folyóirat, évi utolsó szám angol nyelvű, C kategória). Jellemzően, de nem kizárólag önkormányzati dimenziókat dolgoz fel a Comitatus önkormányzati szemle (COMITATUS Társadalomkutató Egyesület, változó évenkénti számmal, 1991-től, C kategória). Vidékfejlesztési témáknak ad otthont A Falu (Hermann Ottó Intézet, 1985-től, negyedévente, C kategória), a területi politika egyes fejezeteit dolgozza fel az akadozó intenzitással megjelenő Falu Város Régió (kormányzati kiadvány, változó évenkénti megjelenéssel 1994-től, C kategória), a Közép-Európai Közlemények (Szegedi Tudományegyetem, változó évenkénti megjelenéssel, 2008-tól, B kategória) pedig területi történeti összefüggések közreadásának is teret ad. A Deturope folyóirat fontos, nemzetközi C kategóriás lap.

Az MTA RTB publikációs listán 58 magyar nyelvű folyóirat szerepel (A kategória: 8, B kategória: 12, C kategória: 23, D kategória: 15 cím), a jelzett regionális tudományra határozottan fókuszáló periodikákon kívül más társadalomtudományi folyóiratok is szívesen adnak helyet a területi témákhoz kapcsolódó, ám az illető folyóirat profiljába tartozó tanulmányoknak.

Az egyéni publikációs aktivitás és hivatkozási vonzerő halmozott adatai az életkorral, az aktív kutatói évekkel korrelálnak, generációk között nem összehasonlíthatók. Egyes esetekben a formális, mennyiségi publikációs követelmények nyomása a publikációk minőségének rovására megy. Hasonlóan más társadalomtudományokhoz, a regionalisták jellemző publikációs formái és fórumai különböznek más tudományterületekétől (pl. a hagyományos természettudományok, az élettudomány domináns folyóiratcikk-orientáltságától), a szakma vezető egyéniségeinek és testületeinek ezt a tényt mindenütt határozottan képviselniük kell.

Sajnálatos, hogy a hazai aktuális tudománymetriai szemlélet az egyetemi oktatáshoz kötődő, mégoly színvonalas tankönyveket lényegében a tudományosságon kívül helyezi, ami mára e forma elhalásához vezetett. Mindez a képzések indokoltnál erősebb diverzifikálódását, dezintegrálódását, túlzott helyi és személyi függését okozza.

\section{Hazai tudományos kutatási források}

A kutatások támogatásának fontos hazai forrását kezdetektől az OTKA-pályázatok jelentették. Szinte minden évben lehetett egy-két nyertes, a regionális tudományhoz kapcsolódó pályázattal számolni. A regionális tudomány nem rendelkezik önálló bírálati bizottsággal, így a pályázóknak a társadalomtudományok (vagy a földtudomány, földrajz) többi ágával kell megküzdenie, de egyidejűleg két bizottságnál lehet indulni.

Az MTA-PTE Innováció és Gazdasági Növekedés kutatócsoport az innováció, vállalkozás, gazdasági fejlődés kérdéskörét tanulmányozza Varga Attila pro- 
fesszor vezetésével a 2012-2022-es időintervallumban. A Lendület Program keretében egy kutatócsoport köthető a regionális tudományokhoz (Agglomeráció és társadalmi kapcsolathálózatok, 2017-2022, vezető: Lengyel Balázs, KRTK). A Bolyai Kutatási Ösztöndíjból nyert támogatásban sem bővelkedik a szakma, viszonylag kevesen részesültek az ösztöndíjban (2011: 1 fo, 2012: 1 fö, 2013: nincs nyertes, 2014: 2 fo, 2015: nincs nyertes, 2016: 1 fó, 2017: 3 fö, 2018: 2 fo, 2019: nincs nyertes). A regionális tudomány képviselete és pályázati aktivitása kimondottan gyengének mondható.

A hazai kormányzati megbízások akadoznak, egy-egy tárca esetlegesen tart igényt a kutatásokra (vidékfejlesztés), de megbízásaikat a kedvelt vagy kötelezően kedvelendő társaságok, intézetek kapják. Hasonló a helyzet az önkormányzatokkal, ott is kötöttpályás letámadás folyik, így a kegyeltek részesednek a megbízásokban. Az EU-forrásokból kutatás-fejlesztésre az egyetemi szféra számára (EFOP, GINOP) elérhetők jelentősebb források (kivéve a közép-magyarországi régiót), az pedig a regionális tudománnyal foglalkozó egységek egyetemen belüli helyzetétől függ, hogy kapnak-e kutatási támogatást, avagy sem. Ezen források felhasználását az erős bürokrácia és a jelentős publikációs teljesítménykényszer jellemzi, így vélhetően születnek a jövőben szakmai eredmények is. Egyéb alapítványi és közösségi megbízásokról nem lehet véleményt mondani, mert nem átláthatóak, elérhető információk nincsenek, úgy látszik, hogy itt is a személyes kapcsolatok a meghatározóak.

\section{Nemzetközi kapcsolatrendszer}

Nemzetközi forrásokról, illetve programokban való magyar jelenlétről nem rendelkezünk autentikus információkkal. Elérhetők az ESPON, a H2020, de más nemzetközi programok is, ki kell emelnünk az EU INTERREG formációkat, ahol - ugyan nem jelentős mértékben - ismertek a kutatási lehetőségek. Sajnálatos, hogy csak alkalmanként, nem kellő rendszerességgel, döntően személyi kapcsolatok révén jelennek meg magyar kutatók, szervezetek a nemzetközi programokban. Nem tudjuk, hogy kimondottan magyar vezetéssel folytak-e az elmúlt öt évben számottevő regionális tudományi kutatások.

A 2003-ban megalakult Magyar Regionális Tudományi Társaság vállalta fel a hídszerepet a magyar kutatók és tudományterületünk két vezető nemzetközi szervezete, az Európai Regionális Tudományi Társaság (ERSA) és a Regionális Tanulmányok Társasága (RSA) között. 2010-ben Pécsett tartották az RSA éves konferenciáját, a 2021-es ERSA konferencia megrendezésének jogát pedig a magyar regionalisták pécsi pályázata nyerte el.

Az utóbbi nagyjából másfél évtized során örvendetes változások történtek kollégáink nemzetközi tudományos aktivitásában. Előbb az RSA konferenciáin, majd az ERSA kongresszusain növekedett meg a hazai kutatók által tartott elöadások száma. Ezzel párhuzamosan folyamatosan egyre több nemzetközi publiká- 
ció jelenik meg a magyar regionális kutatók tollából. Mindez igen fontos nemcsak a hazai regionális tudomány nemzetközi rangja, hanem a kutatók egyéni fejlődése szempontjából is, ugyanis a $\mathrm{PhD}$, az akadémiai doktori fokozat odaítélésében, de a kutatóintézetek és az egyetemi tanszékek rendszeres értékelésében is egyre nagyobb szerepet játszik kutatóink nemzetközi láthatósága. Nem hallgatható ugyanakkor el, hogy a nemzetközi jelenlétet nem kizárólag a tudományos kiválóság határozza meg, hanem az egyes műhelyek és kutatók eltérő financiális pozíciója és kapcsolati hálója is.

A pozitív változások mellett rá kell mutatni arra, hogy a hazai regionális mühelyek közül még viszonylag kis számban találhatóak azok a kutatócsoportok, melyek a nemzetközi élvonalban szerepelnek vezető (A kategóriás folyóiratokban megjelent) tanulmányok folyamatos publikálásával. Ebben a vonatkozásban az KRTK RKI mellett, a PTE (Regionális Innováció- és Vállalkozáskutató Központ), a KRTK (Agglomeráció és Társadalmi Hálózatok Lendület csoport), valamint az SZTE (Közgazdaságtani és Gazdaságfejlesztési Intézet) érdemes említésre. Örvendetes az is, hogy a nemzetközi tudományos életben erősödő pozíciókat elérő mühelyek feladatuknak érzik a többi hazai kutatócsoport segítését a nemzetközi porondra lépés útján.

Fontos momentum, hogy a hazai szakmának szoros, élő kapcsolatai vannak a határon túli magyar regionalista műhelyekkel, kutatókkal, egyetemekkel (elsősorban a vajdasági és erdélyi kapcsolatrendszer erős).

\section{A főbb kutatási tématerületek néhány jellemzője}

\section{Társadalmi térelmélet}

A hazai regionális tudományban vizsgált kérdéskörök közül hosszú ideig hiányoztak a társadalmi térelméleti munkák, legfeljebb néhány elszórt publikáció érintette azokat. A kilencvenes évektől kezdve azonban fordulatnak vagyunk tanúi. Máig több monográfia, fajsúlyos folyóiratcikk jelent meg hazai szerzők tollából. A kevés szakterületi tudományos vita egyike is térelméleti kérdésekhez kötődött a Tér és Társadalom hasábjain. Komoly lökést adott e közelítéseknek a tág társadalomtudományban lezajlott „térfordulat”, ami sok - a térbeliségre korábban lényegében érzéketlen - tudományterület diskurzusaiba is behozta a térbeli, területi szempontot, tartalmat. Szakterületünkön belül örvendetes, hogy a fiatal generáció is bekapcsolódott ezekbe a munkákba, a legújabb írásokban érzékelhetően erősödött a hosszú ideig hiányolt (tér)elméleti megalapozás. Enélkül, például a pusztán egy vagy néhány területet megfigyelési egységként vizsgáló munkák nem sorolhatók a regionális tudomány önálló diszciplináris karakterét erősítő publikációk közé, minőségüktől, értéküktől függetlenül. 


\section{Regionális és városgazdaságtan}

A regionális és városgazdaságtan különböző kérdésköreinek kutatása és publikálása a regionális tudománnyal foglalkozók széles körét érinti. Rendszeresen jelennek meg tanulmányok a hazai térségek gazdasági növekedésével, fejlődésével, versenyképességével, innovációs kapacitásával, a fejlesztéspolitikák hatáselemzésével stb. kapcsolatban. A kutatási eredmények a hazai érdeklődők széles köréhez eljutnak, a tanulmányok nemcsak regionális tudományi, hanem közgazdasági (pl. Közgazdasági Szemle) és gazdálkodástudományi fórumokon (pl. Vezetéstudomány) is rendszeresen megjelennek. A témakör átfogó hazai tankönyvében (Lengyel, Rechnitzer 2004) áttekintett témakörökön túl az új kutatási irányokat is többen művelik és nemzetközi folyóiratokban is publikálják eredményeiket, pl. hálózati kapcsolatok térbelisége, területi tőke, agglomerációs gazdaságok és klaszterek, a tudásáramlás térbelisége, intelligens szakosodás, újraiparosodás.

A kutatási kérdések között eddig háttérbe szorultak a városgazdaságtan bizonyos kulcsterületei, pl. a városi munkaerőpiacok, az ingatlanválasztás, a területhasználat, vagy a városi közlekedés modellezése. A módszertant tekintve főleg a leíró jellegü elemzések dominálnak, de megjelentek a nemzetközi folyóiratok elvárásai szerint készülő elemzések, modellezések is, még ha csak egy szűk szakmai kör műveli is ezeket. Fontos lenne, hogy a nagyméretű adatbázisok feldolgozását és modellezését szélesebb körben is megismerné a hazai regionalista szakma, főleg a fiatal kollégák, amit workshopok szervezésével is elő lehetne segíteni, felkérve neves külföldi előadókat.

\section{A terület-és településfejlődés gazdasági és társadalmi folyamatai}

A hazai regionális tudományban a kezdetektől fogva súlyponti témakör a hazai területi szerkezet elemzése, e szerkezet belső és külső összefüggéseinek feltárása (különféle területi egységek időbeli és összehasonlító elemzése, fejlődési pályák felvázolása, területi erőforrások komplex és egyedi értékelése). A nemzetközi területi kutatás, regionális tudomány fókuszába a hazai történések iránti érdeklődést a radikális társadalmi és a területi átrendeződést hozó rendszerváltozás hozta el. A kilencvenes években a nemzetközi tudományos rendezvényeken, konferenciákon mindig nagy érdeklődés és kollegiális szimpátia kísérte a magyar kutatókat és mondandójukat. A hazai térfolyamatok, a térszerkezet átalakulásának elemzését a szakma színvonalas magyar és idegen nyelvű munkákban tette közzé. Ezeket a munkákat a hazai területfejlesztés meghatározó szereplői is érdemben használták a területfejlesztési politika céljainak, eszközeinek kialakításakor. Mára - összefüggésben a láthatóan megmerevedett, erősen tagolt térszerkezeti képpel - a legújabb kutatások kevesebb újdonsággal szolgálnak a hazai térszerkezeti viszonyokról, fontos új elemként azonban megjelenik bennük a tágabb térbeli kitekintés, az európai folyamatok, a kárpát-medencei tér mint elemzési 
keret. Fontos tematikai elmozdulás az elemzésekben a városi folyamatok középpontba állítása, ez azonban nem hozhatja magával azt, hogy a kritikus helyzetü „perifériák”, régiók a kutatásban is perifériára szoruljanak. Azt is érdemes megfontolnunk, hogy a mára megsokasodott „posztszocialista” tematikájú munkákban mi is aktívabban részt vegyünk, és nem pusztán nyugati kollégáink adatszolgáltató bedolgozóiként, hanem az átfogónak szánt modellek, tanulságok, az „eredmények” társszerzőiként is.

\section{Terület-és vidékfejlesztési politika, tervezés és kormányzás}

A területi politika céljainak, irányainak, hatásainak bemutatása, a fejlesztések eredményeinek, hiányosságainak értékelése, a területi intézményrendszer működésének, a különféle szereplők magatartásának elemzése, a működés gazdasági, társadalmi és intézményi feltételeinek vizsgálata a regionális tudomány kulcsfontosságú, központi témaköre, amelyben szorosan összekapcsolódik a tudományos kutatás és a (szak)politika. Míg az itt röviden jellemzett többi tématerületen folyamatos, törésmentes átalakulás, minőségi fejlődés érezhető, a területi politika 2010-től fokozatosan háttérbe szorult, nem vált a gazdaság- és társadalompolitika integráns részévé, és ez hatással van a kutatási szférára is.

A területi politika irányítását illetően alapjaiban változott a jogi környezet (a területfejlesztés alapvetően megváltozott törvényi szabályozása okán). A kormányzati struktúra átalakult (ebben a területi és települési kérdéskörök, valamint a velük erős kapcsolatban lévő más tématerületek egyértelműen leértékelődtek, a miniszteriális pozíciók folyamatosan változtak, s ezt a változást a helyi szereplők, az önkormányzatok mozgásterének szükülése még tovább súlyosbította). Erőteljessé vált a központosítás, mérséklődött az alulról jövő kezdeményezések szerepe, számos új, eddig nem ismert szervezet kapcsolódott be a fejlesztéspolitika megvalósításába. Megváltozott a financiális és tervezési háttér is (amit az EU-támogatások mozgatnak).

A tudományos kutatások iránti igény minden szinten látványosan csökkent, aminek a következménye, hogy visszaszorultak a témakörhöz kapcsolódó publikációk, nagyobb, átfogó elemzések. A korábbi időszak régióközpontú szemléletére a szakma példaértékủen reagált a Horváth Gyula által kezdeményezett és koordinált Kárpát-medence régiói monográfiasorozattal, a területi centralizáció és decentralizáció viszonyának alakulását több átfogó munka mutatta be. A regionalista közösség aktuális feladata az új irányítási adottságok és viszonyok - egyedi települési, térségi relációk bemutatásán túl, mint amilyen a „győri modellt" példaértékűen bemutató, sokszereplős kutatás volt - átfogó vizsgálata, értékelése, ha indokolt, érdemi kritikája. Érdemes áttekinteni a regionális tudomány értékelő szempontjaival a hazai területi folyamatokat, az intézményrendszer működését, s mindezek hatását a megmerevedett területi fejlettségi tagoltságra. 


\section{Területi statisztika és elemzési módszerek}

A közismert információrobbanás új lehetőségeket (és kockázatokat) hozott a hazai területi elemzők számára is. Az információk és az elemzési módszerek rendeltetésszerü használatának szakmai alapjai az összes szakirányú képzésben követelményként vannak jelen. A magyar és idegen nyelvű szakirodalom, a számítástechnikai eszköztár elérhető. A regionális modellezés módszertani eszköztárában a klasszikus modellek, módszerek mellett a legfontosabb újdonság a (területi) autoregresszív modellek megjelenése. Ma nagy hatású és vonzású eszközként egyre nyilvánvalóbban erősödik a társadalmi térinformatika, szinte már önálló tudományágként, az adatháttér oldaláról pedig a"big data" elemzési kör ad új kutatási impulzusokat. A hazai regionalisták kapcsolódtak hálózatkutatási projektekhez is. Mindezen folyamatok formálják a fiatal regionalista generáció új „szakmai nyelvét”. Ez a kutatási témakör számos speciális felkészültséget igénylő ismeretet integrál, ezért indokolt a publikációk erőteljes szakmai kontrollja. A szakma sokrétűen használja a „puha” módszertani eszközrendszert, ezért érzékletes hiányként jelölhető meg itt egy átfogó magyar nyelvű módszertani munka, amely a területi elemzők szempontjait is figyelembe veszi. Továbbra is indokolt a területi elemzési módszertan önálló témakörként való művelése.

Az itt röviden jellemzett tématerületek természetesen nem zártak, egymást sok esetben átfedik, kiegészítik, maguk is kiegészülnek újabb, izmosodó témakörökkel (ilyenek például a geopolitikai kutatások). Minden tématerületen jelen van a regionális tudomány nemzetközi kutatási irányainak adaptálása, azok eredményeinek, módszereinek feldolgozása, beépítése a hazai területi folyamatok értékelésébe. Elméleti és módszertani tudás, a reálfolyamatok elemzése és az irányítási kérdések egymás mellett, egymásra épülve kapnak helyet a tudományos publikációkban, összekapcsolódnak bennük a különböző társadalmi szférák és a térbeli léptékek is. Ez a szakma tudományos karakterének is fontos sajátossága. Mindez - s természetesen a más tudományterületek eredményeinek nyomon követése, hasznosítása és értelmezése - a regionális tudomány érdemi hozadékkal kecsegtető, fenntartandó kutatási szemlélete.

\section{A regionális tudományhoz kapcsolódó egyetemi képzések}

Az egy évtizede elindult ún. Bologna-rendszerű képzésekben a regionális tudományhoz szorosabban négy mesterszak köthető: regionális és környezet-gazdaságtan, geográfus, szociológia és vidékfejlesztő agrármérnök mesterszakok. Mindegyik mesterszak elindult egy évtizede hét egyetemen, kapcsolódva az egyetemeken működő regionális tudományi műhelyekhez is. A biztató kezdést követően napjainkra komoly visszaesés tapasztalható, a nappali tagozatos hallgatók létszáma kb. kétharmadára csökkent. A mesterszakok esetében már csak két-két egyetemen folyik érdemi képzés (ahol legalább tíz aktív első évfolyamos hallgató 
található), kivéve a geográfust, amelyik négy egyetemen. A regionális és környezet-gazdaságtan mesterszakos képzések vidéken lényegében megszüntek (2017-ben Kaposváron hét diákot vettek fel), és csak a Budapesti Corvinus Egyetemen (az MNB támogatásával) és a Budapesti Műszaki és Gazdaságtudományi Egyetemen (tíz éve, magyar és angol nyelveken) folynak. De e két egyetemen oktatói közül sajnos kevesen kapcsolódnak a hazai regionális tudomány szerveződéseihez, alig vesznek részt a regionális tudományi közéletben. Biztató, hogy szinte az összes magyar egyetemen van kisebb-nagyobb regionális tudományi mühely, de a képzési kínálatban háttérbe szorultak a mesterszakjaink és félö, hogy más szakokon is beszükül a regionális tudományi ismeretanyagot nyújtó tantárgyak köre. A tudományegyetemeken folyó geográfusképzés számos szakirányra/specializációra tagolódik, terület- és településfejlesztő szakirányosok képzése minden egyetemen folyik. A regionális tudományhoz legközelebb álló szakmai tartalommal az ELTE regionális elemző szakiránya működik (mindeddig 80 végzett, „piacképes” mesterszakos hallgatóval), a legnagyobb vonzereje - a változó társadalmi és „nyelvi” környezethez igazodva - ugyanakkor a néhány éve indult geoinformatikai specializációnak van.

Doktori (PhD) fokozatot is két évtizede lehet regionális tudományból szerezni, 2018 végéig 130 fö védte meg dolgozatát. Korábban négy egyetemen volt lehetőség regionális tudományági $\mathrm{PhD}$-fokozat kiadására, mára csak két egyetemen lehetséges, a Szent István Egyetemen és a Széchenyi István Egyetemen. Más tudományágak doktori iskoláiban is aktívak a Regionális Tudományi Bizottsághoz tartozó köztestületi tagok, amit mutat, hogy 30 fó törzstag 12, míg 80 fó témakiíró 24 doktori iskolában. Azaz a tudományos utánpótlás képzését tekintve sok egyetemen vannak jelen a regionális tudományi szakma képviselői. Sajnos a regionális tudományi PhD-fokozatot szerzettek csak mintegy ötöde lépett be az MRTT-be, hasonlóan az RTB köztestületi tagjai közé (ezt a hiányt enyhíti a jelentős számú geográfus alapképzettségű fiatal doktor e testületekben).

\section{Kitekintés, javaslatok, ajánlások}

A hazai regionális tudományt érintő kihívások szorosan összefüggnek a társadalomirányítás, a tudomány- és oktatáspolitika aktuális irányaival. Az ebben a tekintetben fellépő negatív hatások (az irányítási rendszer erősödő centralizáltsága, a tudományos kutatás társadalmi presztízsének megingása, a tudományos intézményrendszert elbizonytalanító átalakítási tervek, a felsőoktatási forráshiány és más tényezők) a tudományon belüli eszközökkel alig ellensúlyozhatók.

Ezt tükrözi vissza az is, hogy tudományágunk vezető testülete (MTA RTB) jellemzően a szakma legfontosabb „belügyeire” (rendezvények menedzselése, publikációs problémakör, tudományos utánpótlás) fókuszál. Indokoltnak tartjuk, hogy ezeken túlmenően a jövőben e testület is határozottabban, szakmai érveléssel alátámasztva hívja fel a figyelmet a centralizált társadalomirányítás veze- 
tő regionalisták által egyértelműen kimutatott veszélyeire, amelyek egyebek mellett a terület- és településfejlesztés szakmaiságát is fenyegetik. Az ilyen, kritikai tartalmú írások természetes megjelenési fóruma a Tér és Társadalom lehet. E vitairat végén néhány, kifejezetten „tudományon belüli” teendőnek tekintett javaslatunk áll.

- Szükséges lenne, hogy több fórumot biztosítsunk a regionális tudomány egyes tématerületeinek bemutatására, azokhoz kapcsolódó szakmai viták lebonyolítására, hagyományos és digitális formák alkalmazásával. Különösen érvényes ez az MTA RTB albizottságaira.

- A hazai regionális tudomány kutatóintézeti bázisa veszélyben van az MTA-t érintő átszervezés következtében. A 35 éves múlttal rendelkező intézet a hazai regionális tudomány gerince, így annak leépítése súlyosan érintené a tudományterületet. A megújítás mellett egyértelműen támogatjuk a bázisintézet folyamatos müködését.

- Célszerű az MTA RTB és az MRTT együttműködésével kidolgozni egy önkéntes kutatásnyilvántartási rendszert, amiben az egyes programok megjelenhetnek, s így alkalmat adnak a részvételre és az eredmények elérhetőségét is megkönnyítik.

- Növelni kell a regionális tudomány képviseletét az akadémiai és a kormányzati pályázatoknál, ösztönözve a szakmánk tagjait, hogy minél nagyobb számban pályázzanak.

- Támogatni szükséges a tudományos karrier építését, különösen az MTA doktora cím pályázásában, mivel a doktori iskolák vezetésében hamarosan (2020-2022 között) váltás következik be, továbbá az érdemes kutatási programvezetőkre is egyre nagyobb szükségünk van.

- A középgenerációnak (35-50 évesek) több fórumot kell adni a bemutatkozásra, ami jelentheti a nagyobb terjedelmű művek (monográfiák, sorozatok) megjelentetését, a konferenciákon való részvételt (vezető előadások, szekcióvezetés) éppen úgy, mint a témavezetést és egyéb tudományos aktivitást.

- A szakmai publikációs fórumokat a jövőben is fenn kell tartani, egyre több angol nyelvű közlemény megjelentésével. A nemzetközi folyóirat-minősítésekre pedig alaposabban és szakszerübben kell felkészülni. Természetesen nem adható fel a szakmai reagálás az égetö, aktuális hazai területi irányítási kérdésekre, magyar nyelven, a szótértés reményében.

- Érdemes lenne publikációs nívódíjat bevezetni, mind a monográfiák, mind a magyar és idegen nyelvü publikációk vonatkozásában. A minősítési rendszer modelljei más MTA bizottságokban működnek, azok gyakorlatát és tapasztalatait érdemes átvenni.

- Szükség van a regionális tudomány eredményeinek népszerüsítésére, közérthető formában való megjelenítésére, határozottan kell élni az internet nyújtotta kommunikációs lehetőségekkel. 
- A regionalistáknak kutatóként, oktatóként, gyakorlati szereplőként a jövőben is támaszkodniuk kell a rokonterületek ismeretrendszerére, eredményeire. Ugyanakkor a szakmán belül fontos etikai szempontként fel kell hívni a figyelmet arra, hogy elfogadhatatlan a tudományági „identitás” ismétlődő, taktikai váltogatása pusztán érdek- vagy karrierszempontok mentén.

Minden nehézség dacára optimizmusra ad okot, hogy a regionális tudományi ismereteket elsajátító legkiválóbb fiatalok a kezdetektől máig jellemzően szakmaközeli helyekre kerülnek az igazgatási, az oktatási-kutatási és a piaci szférában. Ez a regionális tudományi tevékenység, a kutatómunka és az oktatási erőfeszítések életképességének, társadalmi hasznosulásának egyik legmeggyőzőbb visszaigazolása.

\section{IRODALOM}

Lengyel I., Rechnitzer J. (2004): Regionális gazdaságtan. Dialóg Campus Kiadó, Budapest, Pécs (Studia Regionum)

Lengyel I., Rechnitzer J. (szerk.) (2009): A regionális tudomány két évtizede Magyarországon. Akadémiai Kiadó, Budapest (Modern Regionális Tudomány Szakkönyvtár) 